\title{
Role of Cetyltrimethylammonium Bromide in the Green Synthesis of Silver Nanoparticles Using Mimusops elengi, Linn. (Maulsari) Leaf Extract
}

\author{
Rabia Ahmad*, Sajjad Hussain Parrey, Qamer Faisal \\ Department of Chemistry, Faculty of Natural Sciences, Jamia Millia Islamia (Central University), New \\ Delhi, India \\ Email: "rabia.khan422@gmail.com
}

Received 8 December 2015; accepted 12 February 2016; published 15 February 2016

Copyright (C) 2016 by authors and Scientific Research Publishing Inc.

This work is licensed under the Creative Commons Attribution International License (CC BY). http://creativecommons.org/licenses/by/4.0/

(c) (i) Open Access

\begin{abstract}
Mimusops elengi (Maulsari) is a medicinal plant (showing; antioxidant, antimycotic, antidiabetic, analgesic activity, etc.). Conventional UV-visible spectrophotometric technique in the presence of CTAB and transmission electron microscopic technique both in the presence and absence of CTAB were used to determine the morphology of silver nanoplates (AgNP) using Mimusops elengi (Maulsari) aqueous leaves extract for the first time. Cetyltrimethylammonium bromide (CTAB) has no significant effect on the shape of the spectra and position of SPR bands. Effects of various CTAB were also discussed in the green extra-cellular synthesis of AgNP using Mimusops elengi (Maulsari) leaves extract.
\end{abstract}

\section{Keywords}

Nanostructures, Chemical Synthesis, Transmission Electron Microscopy, Surface Properties

\section{Introduction}

The biosynthesis of nanoparticles is receiving immense importance due to the present need to develop environmentally benign technologies in material synthesis. The task of searching new biomaterials for the biosyntheses of nanoparticles continues among researchers worldwide in spite of many synthetic technologies being well documented. Sastry and co-workers have explored the possibility of using microbes and plant materials as nano-

*Corresponding author.

How to cite this paper: Ahmad, R., Parrey, S.H. and Faisal, Q. (2016) Role of Cetyltrimethylammonium Bromide in the Green Synthesis of Silver Nanoparticles Using Mimusops elengi, Linn. (Maulsari) Leaf Extract. Advances in Nanoparticles, 5, 44-52. http://dx.doi.org/10.4236/anp.2016.51005 
factories [1]-[6]. Since that time various plants and microorganisms have been employed for the synthesis of nanoparticles. Nowadays, the "green" synthesis of metal nanoparticles has received increased attention due to the advances in ecofriendly technologies in material science. Gardea-Torresdey et al. [7] [8] initially reported the possibility of using plant materials for the synthesis of nanoscale metals. Later nanosized metals of various shapes were produced by bioreduction, capable of meeting various industrial requirements [4]-[6]. Huang et al. demonstrated the use of sun-dried Cinnamomum camphora leaf for the synthesis of nanosized Ag and Au at ambient conditions without the use of any additives for protecting nanoparticles from aggregation [9]. There is almost no literature on the extra cellular synthesis of Ag-NPs by using sea weeds [10].

Mimusops elengi, Linn. locally known as Maulsari is a medicinal plant which belongs to the Family: Sapotaceae. Since long time parts of the plant are used traditionally in medicine. The aqueous extract of flowers, fruits and bark are mainly used for dental ailments (pyorrhea, dental carries), and also for heart diseases like menorrhagia and leucorrhoea [11]. The plant leaves of this plant are potential source for hydrocarbons. It has been reported that the leaves contain various organic compounds such as alkaloids, flavonoids, tannins, terpenoids, steroids, glycosides and benzenoids [12] [13].

The antibacterial activity of silver and its compounds have been studied for many years. Antibacterial activity of the silver-containing materials can be used for various purposes in medicine to prevent bacteria colonization on catheters, cancer, dental materials, prostheses, stainless steel materials, and vascular grafts [14]-[16]. Over the last two decades many authors have used various biological, chemical, and physical methods for the synthesis of advanced nano-materials of silver and gold [17]-[23]. Generally, a stabilizer (co-polymers, dendrimers, lipids, polymers, surfactants, and starch) is essential to obtain fine and stable noble metal particles obtained by these methods [24]-[26]. In green chemistry hazardous toxic chemicals are avoided and environmentallyfriendly approaches are adopted [27]. The leaf extracts of different plants were used [9] [28]-[35].

Surfactants are amphiphilic in nature with two ends with different polarities and can serve as protecting, capping and/or stabilizing agent for nanoparticles against external forces [36]. There is a broad spectrum of applications of Ag and AgNP and hence several investigators use surfactants in their synthesis according to the chemical reduction method [37]. The roles of surfactants in the green extra-cellular biosynthesis of silver nanoparticles are limited. Transparent solutions of nanometer large particles show negligible scattering of light [38]. UV-Vis spectroscopy can be used for the study of water soluble nano-materials. It can be used to monitor the optical changes that accompany the surface on the materials size and size distribution. The absorbance spectra would be helpful in establishing the aggregation state of nanoparticles.

Survey of the literature reveals that leaf extract of Mimusops elengi, Linn. has been used in the green synthesis of silver nanoparticles. The UV-visible spectroscopy reveals that the surface plasmon resonance peak at 434 nm with high absorbance FTIR measurement was used to predict the role of reducing and stabilizing capacity of Mimusops elengi, Linn. leaf extract. The SEM analysis showed spherical particles in the range of 55 - $83 \mathrm{~nm}$ [11]. To the best of our knowledge there are no reports to investigate the role of cetyltrimethylammonium bromide in the synthesis of silver nanoparticles using Mimusops elengi, Linn. leaf extract. It was, therefore, thought to be of interest to prepare the water soluble silver nano-materials in the absence and presence of CTAB. In the present study, spectra of resulting colored silver sols showed peaks in the visible region. The biosynthesis of different sized bio-conjugated nano-materials is more advantageous than conventional synthetic chemical reduction method due to their environmentally-friendly technologies. Surfactants, especially CTAB [39]-[42], are potentially very useful in understanding the shape transformation of silver and gold. Thus we decided to study the formation kinetics using Mimusops elengi as green reducing agent by the bio-chemical reduction method.

\section{Materials and Methods}

\subsection{Synthesis of Ag-Nanoparticles}

In a typical one step synthesis, silver nanoparticles were prepared by the reduction of $\mathrm{AgNO}_{3}$ (silver nitrate, 99\% Merck India product was used without further purification, aqueous solution was prepared by dissolving the required amount in the distilled water and stored in brown bottle. Double distilled water was used as solvent to prepare all solutions) solutions with Mimusops elengi Linn leaf extract. Fresh 10 gm leaves were obtained from campus of Jamia Millia Islamia (Central University), New Delhi. The leaves were washed with cooled water and chopped into fine pieces then soaked in $250 \mathrm{ml}$ double distilled water, heated for $20 \mathrm{~min}$ on water bath at $60^{\circ} \mathrm{C}$. The Mimusops elengi, L. (Maulsari) leaves extract was filtered with Whatman paper No. 1 and kept under con- 
tinuous dark conditions to avoid the intervention of photochemical reactions. $5.0 \mathrm{~cm}^{3}$ of leaf extract was added to $5.0 \mathrm{~cm}^{3}$ of $1.0 \times 10^{-2} \mathrm{~mol} \cdot \mathrm{dm}^{-3} \mathrm{AgNO}_{3}$ and the volume was adjusted to $50 \mathrm{~cm}^{3}$ with double distilled water for the green reduction process. In order to establish the role of CTAB (98\% purity) in the green biosynthesis of Ag-nanoparticles, pre and post micellar concentration of CTAB were also used under different experimental conditions, we took $\left[\mathrm{Ag}^{+}\right]=10.0 \times 10^{-4}$ to $30.0 \times 10^{-4} \mathrm{~mol} \cdot \mathrm{dm}^{-3}$, $[\mathrm{CTAB}]=4.0 \times 10^{-4}$ to $16.0 \times 10^{-4} \mathrm{~mol} \cdot \mathrm{dm}^{-3}$.

\subsection{Characterization of Ag-Nanoparticles}

Upon mixing aqueous solutions of leaf extract and $\mathrm{AgNO}_{3}\left(=10.0 \times 10^{-4} \mathrm{~mol} \cdot \mathrm{dm}^{-3}\right)$, a readily distinguishable pale yellow to dark red colour appears immediately at room temperature. These studies suggest that appearance of colour was due to the formation of Ag nanoparticles [31] [43] [44]. The most characteristic part of Ag-nanoparticles is the surface plasmon resonance transitions observable in the $300-700 \mathrm{~nm}$ regions. The absorption spectrum of coloured reaction mixture was recorded on a UV-visible recording spectrophotometer HITACHI $U$ 3900 with $1 \mathrm{~cm}$ quartz cuvettes under different experimental conditions.

TEM and SAED (Tecnai F 20 TWIN, Model-Tecnai Feg, (FEI) Nether land, 200 KV, 300 grid) studies were performed on a transmission electron microscope. Samples were prepared by placing a drop of working solution on a carbon-coated standard copper grid (300 mesh) operating at $80 \mathrm{kV}$ and allowing the solvent to evaporate in open air at room temperature.

\section{Result and Discussion}

\subsection{Morphology of Ag-Nanoparticles without Stabilizer}

In the first set of experiments, the process of shape evolution was monitored by recording the ultraviolet-visible spectra as a function of time because the shape and nature of the spectra gives preliminary information about the size and size distribution of the silver nanoparticles. It was visually observed that the aqueous silver nitrate solution was turned to dark red which appears immediately at room temperature and indicates the formation of AgNP. It may be due to the excitation of surface plasmon resonance effect and reduction of $\mathrm{Ag}^{+}$ions by leaf extract [45]. The control leaf extract solution (without $\mathrm{Ag}^{+}$ions) showed no change of colour. As shown in Figure 1 , all the spectra have one broad peak in common located at $425 \mathrm{~nm}$. Similar spectra were obtained during the green reduction of Mimusops elengi leaves extract [11]. We point out that no significant changes occurred in the position of absorption band with time (Figure 1). In the second set of experiments, in order to see the effects of $\left[\mathrm{Ag}^{+}\right]$on the growth of Ag-nanoparticles, a series of kinetic experiments were performed at different concentrations of $\mathrm{Ag}^{+}$ions.

The results are depicted in Figure 2 as absorbance-time profiles. Silver ions are reduced and nucleation takes place rapidly in the initial period and then slowly later on. Interestingly, reaction-time curves clearly indicate the increasing $\left[\mathrm{Ag}^{+}\right]$had a marked negative effect on the SPR of Ag-nanoparticles. Such type of behavior may

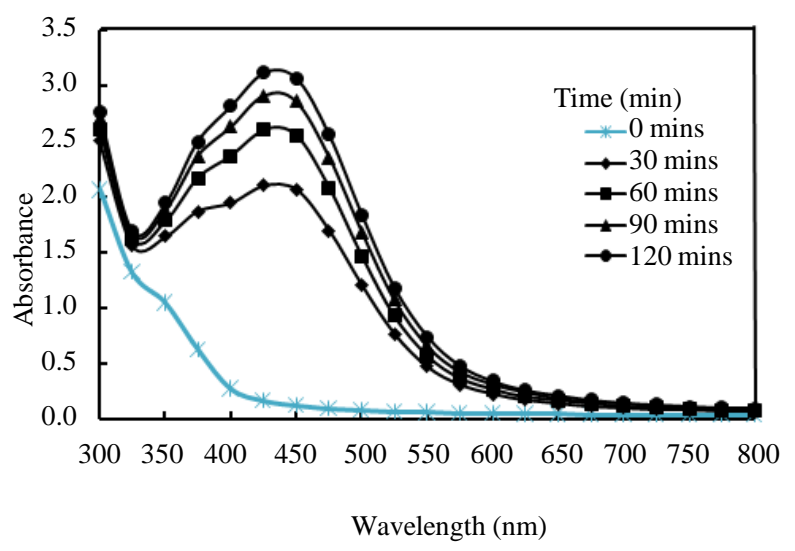

Figure 1. UV-Vis spectra of an aqueous solution of Mimusops elangi (Maulsari) leaf extract and $\mathrm{Ag}^{+}$ions at different time intervals $(\rightarrow-\downarrow)$ ). Reaction conditions $\left[\mathrm{Ag}^{+}\right]$ $=10 \times 10^{-4} \mathrm{~mol} \cdot \mathrm{dm}^{-3}$, Temperature $30^{\circ} \mathrm{C}$. 


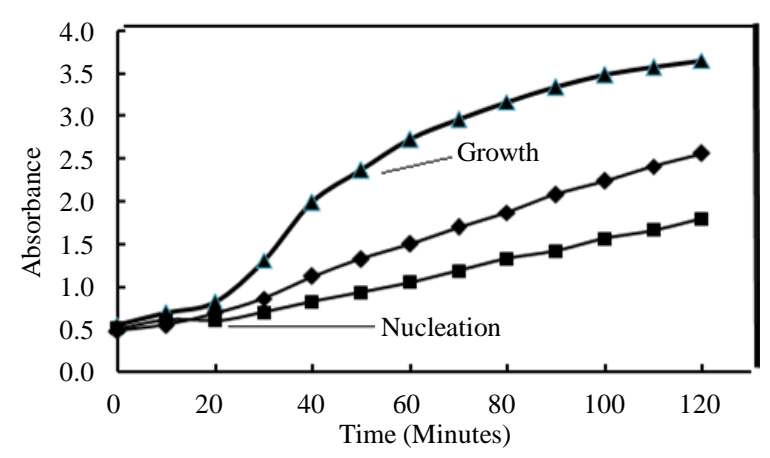

Figure 2. Effect of $\left[\mathrm{Ag}^{+}\right]$on the SPR of biosynthesized Ag-nanoparticles. Reaction conditions $\left[\mathrm{Ag}^{+}\right]=10.0(\boldsymbol{\Delta})$, $20.0(\bullet)$ and $30.0 \times 10^{-4} \mathrm{~mol} \cdot \mathrm{dm}^{-3}(\bullet)$.

be explained in terms of absorption of $\mathrm{Ag}^{+}$ions onto the surface of resulting metallic $\mathrm{Ag}^{0}$ silver particles which, increases the Fermi level of particles [36] [38] [46] [47]. It can now be stated confidently that the perfectly transparent red colour formation is not directly proportional to the $\left[\mathrm{Ag}^{+}\right]\left(\right.$small $\left[\mathrm{Ag}^{+}\right]$being enough to initiate the formation of metal nucleation center which acts as a catalyst for the reduction of other $\mathrm{Ag}^{+}$ions present in solution).

Figure 3 shows the TEM images and SAED pattern of the Ag-nanoparticles at 50 and $100 \mathrm{~nm}$ scales. The resulting nanoparticles are spherical and irregular in shape with some triangular ones. The size ranges from 7 to 21 $\mathrm{nm}$. The nanoparticles are highly crystalline in nature as shown by SAED (Figure 3(b)). The Debye Scherrer ring patterns are consistent with the plane families $\{111\},\{200\},\{220\},\{311\}$ and $\{331\}$ of pure face-centered cubic silver structure [48]. They show particle aggregation. It has been reported that the leaves contain various organic compounds such as alkaloids, flavonoids, tannins, terpenoids, steroids, glycosides and benzenoids [12], [13]. There is a faint layer of other material surrounding the particles which might be due to the capping organic material of Mimusops elengi Linn. leaf extract. The water soluble compounds present in the aqueous extract were found to be responsible for efficient stabilization of nanoparticles and reduction of metal ions. Thus we may safely conclude that the leaf extract acts as reducing, stabilizing and capping agent.

\subsection{Effect of CTAB on the Morphology of Ag-Nanoparticles}

It is well known that a surfactant especially CTAB, is required as a shape directing agent to the synthesis of multi-branched and/or multipods by preferential absorbing on specific crystal planes [26] [49]-[53]. In order to see the role of cationic CTAB surfactant in the green synthesis of Ag-nanoparticles, a series of experiments were carried out under different [CTAB] (range from $4.0 \times 10^{-4} \mathrm{~mol} \cdot \mathrm{dm}^{-3}$ to $16.0 \times 10^{-4} \mathrm{~mol} \cdot \mathrm{dm}^{-3}$ ) at constant $\left[\mathrm{Ag}^{+}\right]$ $\left(10.0 \times 10^{-4} \mathrm{~mol} \cdot \mathrm{dm}^{-3}\right)$ and [leaf extract] $\left(5.0 \mathrm{~cm}^{3}\right)$ at $30^{\circ} \mathrm{C}$. The spectra of brownish red coloured silver solution at different time intervals are depicted graphically in Figure 4. Inspection of these data indicates that not much change has taken place in the position and shape of the spectra except that in the initial period of 30 minutes the absorbance of the solution has been reduced.

The morphology of resulting particles was confirmed by TEM observations. Figure 5 and Figure 6 depict the TEM images of the Ag-nanoparticles prepared at different [CTAB]. For lower [CTAB] $=\left(4.0 \times 10^{-4} \mathrm{~mol} \cdot \mathrm{dm}^{-3}\right)$ the resulting nanoparticles are spherical and irregular in shape with some triangular ones (Figure 5(a)). The size ranges from 4 - $28 \mathrm{~nm}$. There are some large particles $(10-20 \mathrm{~nm})$ and some smaller ones (smaller than $8 \mathrm{~nm}$ ). The nanoparticles are highly crystalline in nature as shown by SAED (Figure 5(b)). TEM images of particles at higher [CTAB] clearly show the same kind of particles of the same shape in the range $3-22 \mathrm{~nm}$ (Figure 6(a)). The nanoparticles are crystalline in nature as shown by SAED (Figure 6(b)). These observations show that size, shape and size distribution of the Ag-nanoparticles are not significantly different in the absence and presence of [CTAB]. Thus we may conclude that CTAB does not have any shape directing role.

From detailed absorbance-time studies (Figure 7) the absorbances are found to decrease with [CTAB] when the reaction was carried above the critical micellar concentration of the CTAB. This is due to the association, incorporation and/or solubilization of Mimusops elengi leaf extract into the micellar palisade and Stern layer of CTAB micelles takes place through hydrophobic interactions. On the other hand, $\mathrm{Ag}^{+}$ions are preferentially 


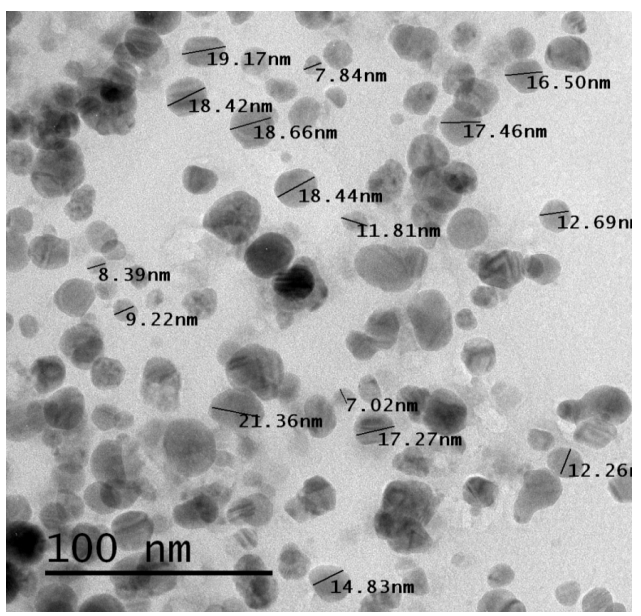

(a)

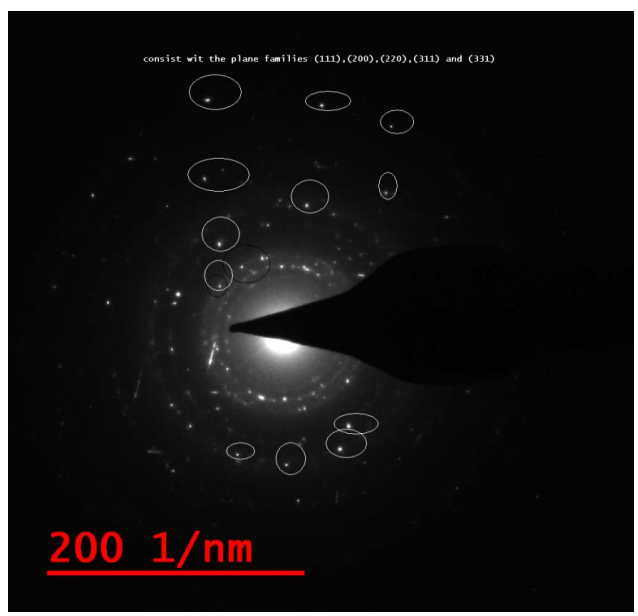

(b)

Figure 3. (a) TEM and (b) SAED images of biosynthesized Ag-nanoparticles using Mimusops elengi (Maulsari) leaf extract. Reaction condition $\left[\mathrm{Ag}^{+}\right]=10.0 \times 10^{-4} \mathrm{~mol} \cdot \mathrm{dm}^{-3}$.

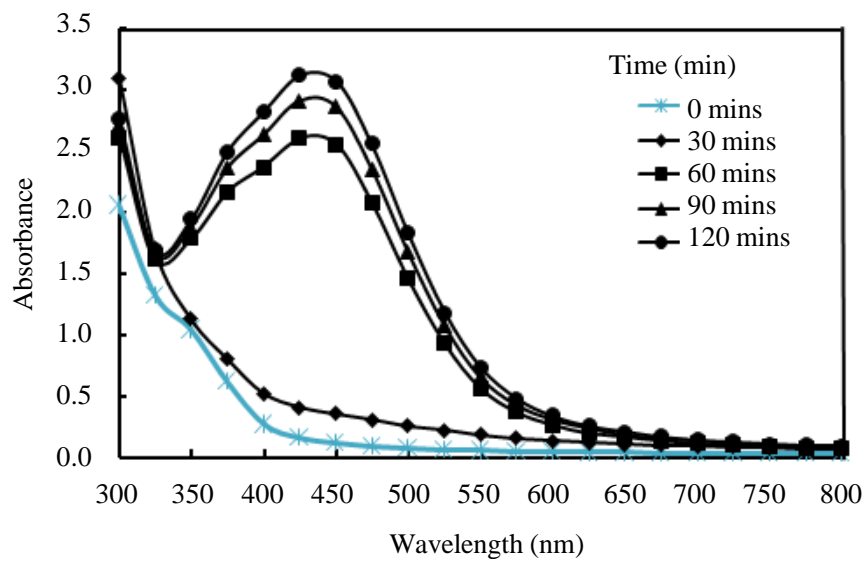

Figure 4. UV-Vis spectra of an aqueous solution of biosynthesized Ag-nanoparticles in presence of CTAB $\left(10.0 \times 10^{-4} \mathrm{~mol} \cdot \mathrm{dm}^{-3}\right)$ at $30^{\circ} \mathrm{C}$. Reaction conditions $\left[\mathrm{Ag}^{+}\right]=10 \times 10^{-4} \mathrm{~mol} \cdot \mathrm{dm}^{-3}$.

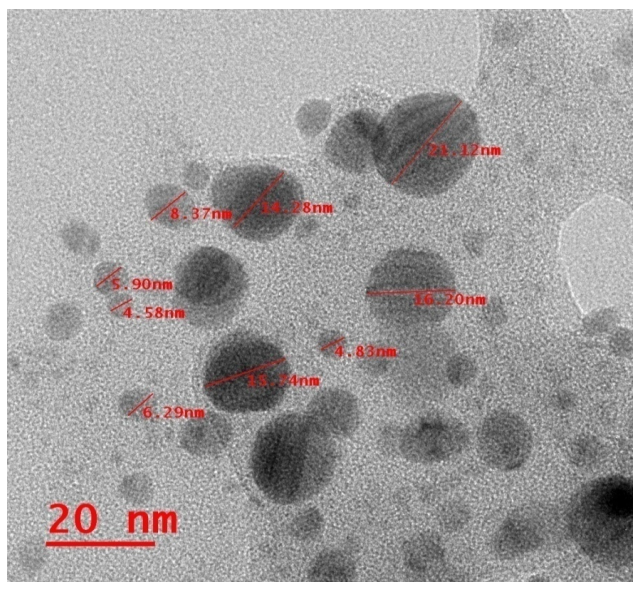

(a)

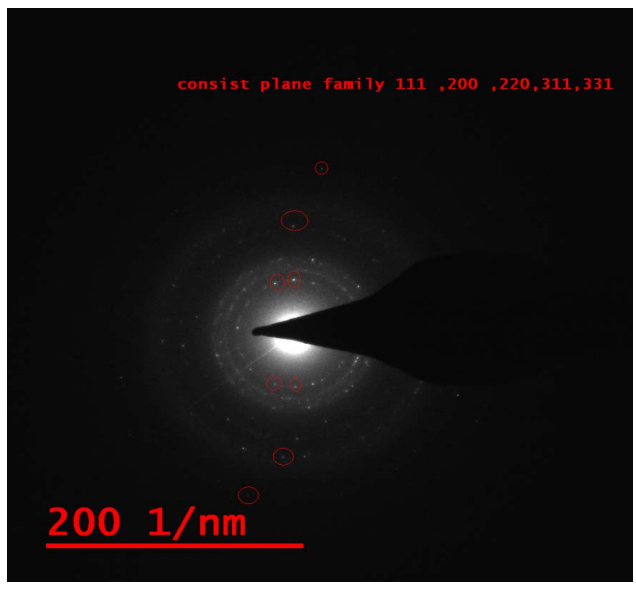

(b)

Figure 5. (a) TEM and (b) SAED images of biosynthesized Ag-nanoparticles using Mimusops elengi (Maulsari) leaf extract in presence of CTAB $\left(4.0 \times 10^{-4} \mathrm{~mol} \cdot \mathrm{dm}^{-3}\right)$. Reaction condition $\left[\mathrm{Ag}^{+}\right]=10.0$ $\times 10^{-4} \mathrm{~mol} \cdot \mathrm{dm}^{-3}$. 


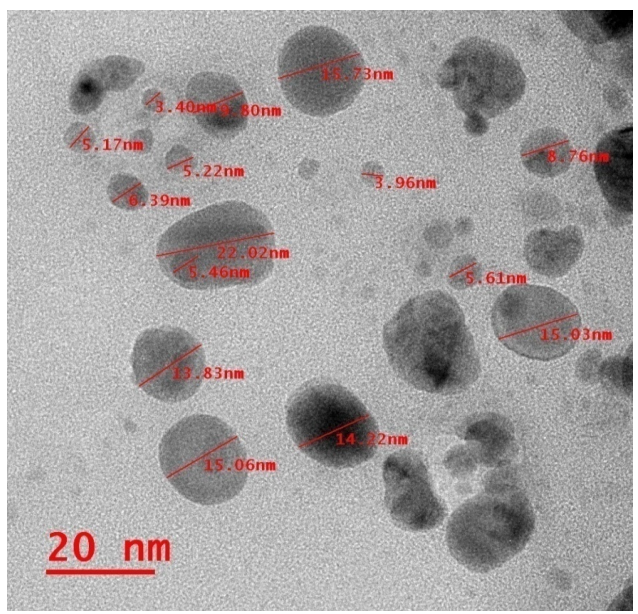

(a)

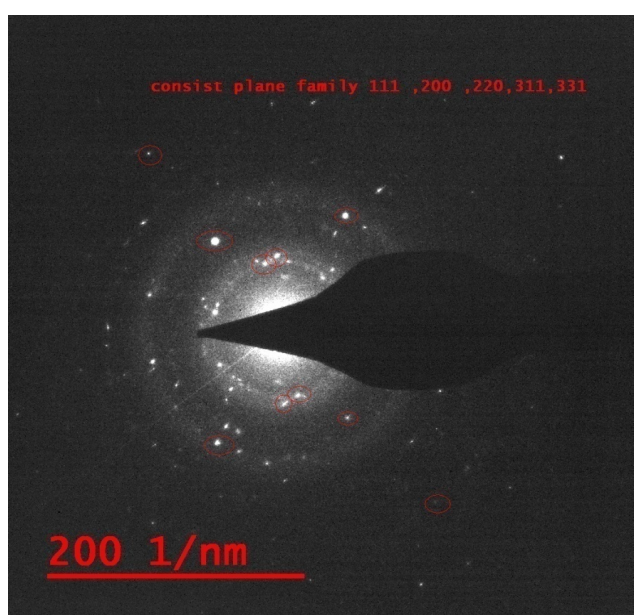

(b)

Figure 6. (a) TEM and (b) SAED images of biosynthesized Ag-nanoparticles using Mimusops elengi (Maulsari) leaf extract in presence of CTAB $\left(10.0 \times 10^{-4} \mathrm{~mol} \cdot \mathrm{dm}^{-3}\right)$. Reaction condition $\left[\mathrm{Ag}^{+}\right]=10.0$ $\times 10^{-4} \mathrm{~mol} \cdot \mathrm{dm}^{-3}$.

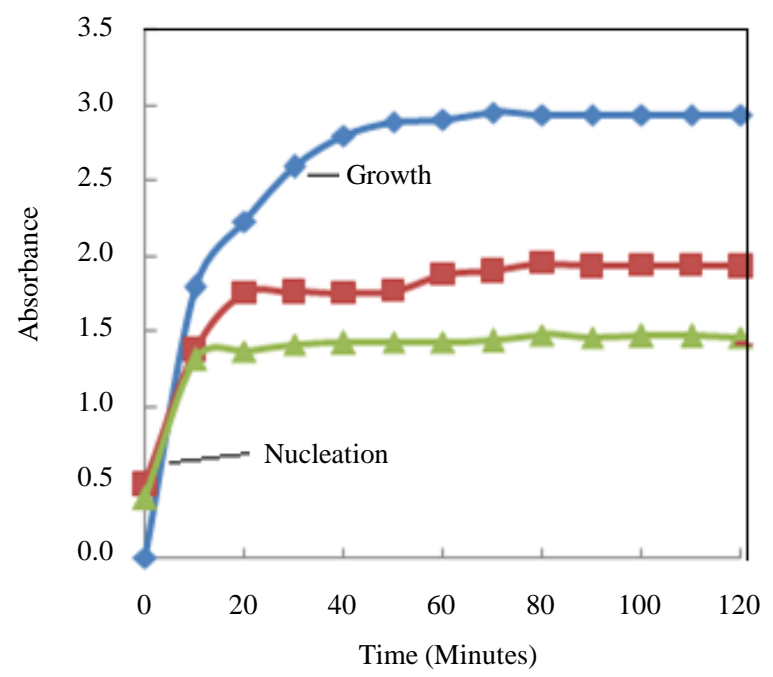

Figure 7. Effect of $\left[\mathrm{Ag}^{+}\right]$on the SPR of biosynthesized Ag-nanoparticles at $30^{\circ} \mathrm{C}$. Reaction conditions: $\left[\mathrm{Ag}^{+}\right]=10.0 \times 10^{-4} \mathrm{~mol} \cdot \mathrm{dm}^{-3},[\mathrm{CTAB}]=4.0 \times 10^{-4}(\star), 10.0\left(\right.$ ㅁ) and $16.0 \times 10^{-4} \mathrm{~mol} \cdot \mathrm{dm}^{-3}($ ) $)$.

located in the water rich Stern layer [54]-[56] and the $\mathrm{Ag}^{+}$ions were reduced into $\mathrm{Ag}^{\mathrm{o}}$. The reaction site i.e. Stern layer has a high population of $\mathrm{Ag}^{\mathrm{o}}$ atoms. That results, single $\mathrm{Ag}^{\mathrm{o}}$ to adsorb, nucleate or complex with $\mathrm{Ag}^{+}$ and grow into silver clusters $\left[\mathrm{Ag}_{4}^{2+}\right]$ [46] [47]. Therefore the further reduction of $\mathrm{Ag}^{+}$ions may be regarded as finished. The nanoparticles are protected, stabilized, and/or capped by a thin layer of Mimusops leaf constituents along with the CTAB (Figure 6(a)).

\section{Conclusion}

Mimusops elengi, L. (Maulsari) leaves extract with surfactant CTAB was successfully used for the synthesis of bio-conjugated silver nano-materials. This spanking new and simple method for biosynthesis of silver nanoparticles offers a valuable contribution in the area of green synthesis and nanotechnology. Interestingly, sub-micellar, post-micellar and dilution effect of CTAB was not observed in the present system because constituents of Mimusops elengi, L. (Maulsari) leaves extract are better capping agents. Carefully monitoring the absorbancetime functions is sensitive technique which allows an easy overview in determining if any nanoparticles aggregation has occurred on to the surface of nano-materials. 


\section{Acknowledgements}

The authors wish to thank Prof. Zaheer Khan, former Professor in the Department of Chemistry, Jamia Millia Islamia (Central University) for introducing us to green nanochemistry.

\section{References}

[1] Mukherjee, P., Ahmad, A., Mandal, D., Senapati, S., Sankar, S.R., Khan, M.I., Parishcha, R., Ajay Kumar, P.V., Alam, M., Kumar, R. and Sastry, M. (2001) Fungus Mediated Synthesis of Silver Nanoparticles and Their Immobilization in the Mycelia Matrix: A Novel Biological Approach to Nanopartcle Synthesis. Nano Letters, 1, 515-519. http://dx.doi.org/10.1021/nl0155274

[2] Ahmad, A., Mukharjee, P, Mandal, D., Senapati, S., Khan, M.I., Kumar, R. and Sastry, M. (2002) Enzyme Mediated Extracellular Synthesis of CdS Nanoparticles by the Fungus, Fusarium oxysporum. Journal of the American Chemical Society, 124, 12108-12109. http://dx.doi.org/10.1021/ja027296o

[3] Sastry, M., Ahmad, A., Khan, M.I. and Kumar, R. (2003) Biosynthesis of Metal Nanoparticles Using Fungi and Actinomycete. Current Science, 85, 162-170.

[4] Shankar, S.S., Ahmad, A. and Sastry, M. (2003) Geranium Leaf Assisted Biosynthesis of Silver Nanoparticles. Biotechnology Progress, 19, 1627-1631. http://dx.doi.org/10.1021/bp034070w

[5] Shankar, S.S., Rai, A., Ankamwar, B., Singh, A., Ahmad, A. and Sastry, M. (2004) Biological Synthesis of Triangular Gold Nanoprisms. Nature Materials, 3, 482-488. http://dx.doi.org/10.1038/nmat1152

[6] Rai, A., Singh, A., Ahmad, A. and Sastry, M. (2006) Role of Halide Ions and Temperature on the Morphology of Biologically Synthesized Gold Nanotriangles. Langmuir, 22, 736-741. http://dx.doi.org/10.1021/la052055q

[7] Gardea-Torresdey, J.L., Parsons, J.G., Dokken, K., Peralta-Videa, J.R., Troiani, H., Santiago, P. and Jose Yacaman, M. (2002) Formation and Growth of Au Nanoparticles inside Live Alfafa Plants. Nano Letters, 2, 397-401. http://dx.doi.org/10.1021/nl015673+

[8] Gardea-Torresdey, J.L., Gomez, E., Peralta-Videa, J.R., Parsons, J.G., Troiani, H. and Jose Yacaan, M. (2003) Alfafa Sprouts: A Natural Source for Synthesis of Silver Nanoparticles. Langmuir, 19, 1357-1361. http://dx.doi.org/10.1021/la020835i

[9] Huang, J., Li, Q., Sun, D., Lu, Y., Su, Y., Yang, X., Wang, H., Wang, Y., Shao, W., He, N., Hong, J. and Chen, C. (2007) Biosyntheiss of Silver and Gold Nanoparticles by Novel Sundried Cinnamomum camphora Leaf. Nanotechnology, 18, 105104-105115. http://dx.doi.org/10.1088/0957-4484/18/10/105104

[10] Govindaraju, K., Kiruthiga, V., Ganesh Kumar, V. and Singaravelu, G. (2009) Extracellular Synthesis of Silver Nanoparticles by a Marine Alga, Sargassum wightii Grevilli and Their Antibacterial Effects. Journal of Nanoscience and Nanotechnology, 9, 5497-5501. http://dx.doi.org/10.1166/jnn.2009.1199

[11] Prakash, P., Gnanaprakasam, P., Emmanuel, R., Arokiyaraj, S. and Saravanan, M. (2013) Green Synthesis of Silver Nanoparticles from Leaf Extract of Mimusops elengi, Linn. for Enhanced Antibacterial Activity against Multi Drug Resistant Clinical Isolates. Colloids and Surfaces B: Biointerfaces, 108, 255-259. http://dx.doi.org/10.1016/j.colsurfb.2013.03.017

[12] Sahaa, M.R., Hasana, S.M.R., Aktera, R., Hossaina, M.M., Alamb, M.S., Alam, M.A. and Mazumdar, M.E. (2008) In Vitro Free Radical Scavenging Activity of Methanol Extract of the Leaves of Mimusops elengi Linn. Bangladesh Journal of Veterinary Medicine, 6, 197-202.

[13] Satish, S., Raghavendra, M.P., Mohana, D.C. and Raveesha, K.A. (2008) Antifungal Activity of a Known Medicinal Plant Mimusops elengi L. against Grain Moulds. Journal of Agricultural Technology, 4, 151-165.

[14] Riley, D.K., Classen, D.C., Stevens, L.E. and Burke, J.P. (1995) A Large Randomized Clinical Trial of a SilverImpregnated Urinary Catheter: Lack of Efficacy and Staphylococcal Superinfection. American Journal of Medicine, 98, 349-356. http://dx.doi.org/10.1016/S0002-9343(99)80313-1

[15] Crabtree, J.H., Burchette, R.J., Siddiqi, R.A., Huen, I.T., Hadnott, L.L. and Fishman, D.A. (2003) The Efficacy of Silver-Ion Implanted Catheters in Reducing Peritoneal Dialysis-Related Infections. Peritoneal Dialysis International, 23, 368-374.

[16] Dastjerdi, R., Montazer, M. and Shahsavan, S. (2009) A New Method to Stabilize Nanoparticles on Textile Surfaces. Colloids and Surfaces A: Physicochemical and Engineering Aspects, 345, 202-210. http://dx.doi.org/10.1016/j.colsurfa.2009.05.007

[17] Yin, H., Yamamoto, T., Wada, Y. and Yanagida, S. (2004) Large-Scale and Size-Controlled Synthesis of Silver Nanoparticles under Microwave Irradiation. Materials Chemistry and Physics, 83, 66-70. http://dx.doi.org/10.1016/j.matchemphys.2003.09.006

[18] Zhu, Z., Kai, L. and Wang, Y. (2006) Synthesis and Applications of Hyperbranched Polyesters-Preparation and Cha- 
racterization of Crystalline Silver Nanoparticles. Materials Chemistry and Physics, 96, 447-453. http://dx.doi.org/10.1016/j.matchemphys.2005.07.067

[19] Duran, N., Marcato, P.L., Alves, O.L. and De Souza, G.I. (2005) Mechanistic Aspects of Biosynthesis of Silver Nanoparticles by Several Fusarium oxysporum Strains. Journal of Nanobiotechnology, 3, 1-7. http://dx.doi.org/10.1186/1477-3155-3-8

[20] Mitra, D.V.B., Sant, S.B. and Annamalai, A. (2012) Green-Synthesis and Characterization of Silver Nanoparticles by Aqueous Leaf Extracts of Cardiospermum helicacabum L. Drug Invention Today, 4, 340-344.

[21] Jana, N.R., Gearheart, L. and Murphy, C.J. (2001) Seeding Growth for Size Control of 5-40 nm Diameter Gold Nanoparticles. Langmuir, 17, 6782-6786. http://dx.doi.org/10.1021/la0104323

[22] Pileni, M.-P. (2003) The Role of Soft Colloidal Templates in Controlling the Size and Shape of Inorganic Nanocrystals. Nature Materials, 2, 145-150. http://dx.doi.org/10.1038/nmat817

[23] Nikoobakht, B. and El-Sayed, M.A. (2003) Preparation and Growth Mechanism of Gold Nanorods (NRs) Using SeedMediated Growth Method. Chemistry of Materials, 15, 1957-1962. http://dx.doi.org/10.1021/cm0207321

[24] Esumi, K., Hosoya, T., Suzuki, A. and Torigoe, K. (2000) Formation of Gold and Silver Nanoparticles in Aqueous Solution of Sugar-Persubstituted Poly(amidoamine) Dendrimers. Journal of Colloid and Interface Science, 226, 346-352. http://dx.doi.org/10.1006/jcis.2000.6849

[25] Chen, J., Herricks, T. and Xia, Y. (2005) Polyol Synthesis of Platinum Nanostructures: Control of Morphology through the Manipulation of Reduction Kinetics. Angewandte Chemie International Edition, 44, 2589-2592. http://dx.doi.org/10.1002/anie.200462668

[26] Bakshi, M.S., Possmayer, F. and Petersen, N.O. (2008) Aqueous-Phase Room-Temperature Synthesis of Gold Nanoribbons: Soft Template Effect of a Gemini Surfactant. The Journal of Physical Chemistry C, 112, 8259-8265. http://dx.doi.org/10.1021/jp801306x

[27] Anastas, P.T. and Warner, J.C. (1998) (2010) (2011) Twelve Principles of Green Chemistry. Green Chemistry: Theory and Practice. Oxford University Press, New York.

[28] Kaviya, S., Santhanalakshmi, J. and Viswanathan, B. (2012) Biosynthesis of Silver Nano-Flakes by Crossandra infundibuliformis Leaf Extract. Materials Letters, 67, 64-66. http://dx.doi.org/10.1016/j.matlet.2011.09.023

[29] Krishnaraj, C., Jagan, E.G., Rajasekar, S., Selvakumar, P., Kalaichelvan, P.T. and Mohan, N. (2010) Synthesis of Silver Nanoparticles Using Acalypha indica Leaf Extracts and Its Antibacterial Activity against Water Borne Pathogens. Colloids and Surfaces B: Biointerfaces, 76, 50-56. http://dx.doi.org/10.1016/j.colsurfb.2009.10.008

[30] MubarakAli, D., Thajuddin, N., Jeganathan, K. and Gunasekaran, M. (2011) Plant Extract Mediated Synthesis of Silver and Gold Nanoparticles and Its Antibacterial Activity against Clinically Isolated Pathogens. Colloids and Surfaces B: Biointerfaces, 85, 360-365. http://dx.doi.org/10.1016/j.colsurfb.2011.03.009

[31] Shankar, S.S., Rai, A., Ahmad, A. and Sastry, M. (2004) Rapid Synthesis of Au, Ag, and Bimetallic Au Core-Ag Shell Nanoparticles Using Neem (Azadirachta indica) Leaf Broth. Journal of Colloid Interface Science, 275, 496-502. http://dx.doi.org/10.1016/j.jcis.2004.03.003

[32] Yilmaz, M., Turkdemir, H., Akif Kilic, M., Bayram, E., Cicek, A., Mete, A. and Ulug, B. (2011) Biosynthesis of Silver Nanoparticles Using Leaves of Stevia rebaudiana. Materials Chemistry and Physics, 130, 1195-1202. http://dx.doi.org/10.1016/j.matchemphys.2011.08.068

[33] Dwivedi, A.D. and Gopal, K. (2010) Biosynthesis of Silver and Gold Nanoparticles Using Chenopodium album Leaf Extract. Colloids and Surfaces A: Physicochemical and Engineering Aspects, 369, 27-33. http://dx.doi.org/10.1016/j.colsurfa.2010.07.020

[34] Ghosh, S., Patil, S., Ahire, M., Kitture, R., Kale, S., Pardesi, K., Cameotra, S.S., Bellare, J., Dhavale, D.D., Jabgunde, A. and Chopade, B.A. (2012) Synthesis of Silver Nanoparticles Using Dioscorea bulbifera Tuber Extract and Evaluation of Its Synergistic Potential in Combination with Antimicrobial Agents. International Journal of Nanomedicine, 7, 483-496.

[35] Jegadeeswaran, P., Shivaraj, R. and Venckatesh, R. (2012) Green Synthesis of Silver Nanoparticles from Extract of Padina tetrastromatica Leaf. Digest Journal of Nanomaterials and Biostructures, 7, 991-998.

[36] Burda, C., Chen, X.B., Narayanan, R. and El-Sayed, M.A. (2005) Chemistry and Properties of Nanocrystals of Different Shapes. Chemical Reviews, 105, 1025-1102. http://dx.doi.org/10.1021/cr030063a

[37] Khan, Z., Hussain, J.I. and Hashmi, A.A. (2012) Shape-Directing Role of Cetyltrimethylammonium Bromide in the Green Synthesis of Ag-Nanoparticles Using Neem (Azadirachta indica) Leaf Extract. Colloids and Surfaces B: Biointerfaces, 95, 229-234. http://dx.doi.org/10.1016/j.colsurfb.2012.03.002

[38] Henglein, A. (1993) Physicochemical Properties of Small Metal Particles in Solution: "Microelectrode” Reactions, Chemisorption, Composite Metal Particles, and the Atom-to-Metal Transition. Journal of Physical Chemistry, 97, 5457-5471. http://dx.doi.org/10.1021/j100123a004 
[39] Zhai, X. and Efrima, S. (1996) Silver Colloids and Macroemulsions of Metal Interfacial Colloidal Films: Interaction with Dithizone. Journal of Physical Chemistry B, 100, 10235-10242. http://dx.doi.org/10.1021/jp9529073

[40] Lou, X.W., Yuan, C. and Archer, L.A. (2006) An Unusual Example of Hyperbranched Metal Nanocrystals and Their Shape Evolution. Chemistry of Materials, 18, 3921-3923. http://dx.doi.org/10.1021/cm0606880

[41] Bakr, O.M., Wunsch, B.H. and Stellacci, F. (2006) High-Yield Synthesis of Multi-Branched Urchin-Like Gold Nanoparticles. Chemistry of Materials, 18, 3297-3301. http://dx.doi.org/10.1021/cm060681i

[42] Chaudhari, V.R., Haram, S.K., Kulshreshtha, S.K., Bellre, J.R. and Hasan, P.A. (2007) Micelle Assisted Morphological Evolution of Silver Nanoparticles. Colloids and Surfaces A: Physicochemical Engineering Aspects, 301, 475-480. http://dx.doi.org/10.1016/j.colsurfa.2007.01.025

[43] Xie, J., Lee, J.Y., Wang, D.I.C. and Ting, Y.P. (2007) Silver Nanoplates: From Biological to Biomimetic Synthesis. ACS Nano, 1, 429-439. http://dx.doi.org/10.1021/nn7000883

[44] El-Sayed, M.A. (2001) Some Interesting Properties of Metals Confined in Time and Nanometer Space of Different Shapes. Accounts of Chemical Research, 34, 257-264. http://dx.doi.org/10.1021/ar960016n

[45] Mulvaney, P. (1996) Surface Plasmon Spectroscopy of Nanosized Metal Particles. Langmuir, 12, 788-800. http://dx.doi.org/10.1021/la9502711

[46] Harada, M., Inada, Y. and Nomura, M. (2009) In Situ Time-Resolved XAFS Analysis of Silver Particle Formation by Photoreduction in Polymer Solutions. Journal of Colloid Interface Science, 337, 427-438. http://dx.doi.org/10.1016/j.jcis.2009.05.035

[47] Harada, M., Sayo, K., Sakamoto, N. and Ito, K. (2010) Characterization of Water/AOT/Benzene Microemulsions during Photoreduction to Produce Silver Particles. Journal of Colloid Interface Science, 343, 423-432. http://dx.doi.org/10.1016/j.jcis.2009.12.006

[48] Guzman, M.G., Dille, J. and Godet, S. (2008) Synthesis of Silver Nanoparticles by Chemical Reduction Method and Their Antibacterial Activity. World Academy of Science, Engineering and Technology, 43, 357-364.

[49] Jin, R., Cao, Y.W., Mirkin, C.A., Kelly, K.L., Schatz, G.C. and Zheng, J.G. (2001) Photoinduced Conversion of Silver Nanospheres to Nanoprisms. Science, 294, 1901-1903. http://dx.doi.org/10.1126/science.1066541

[50] Chen, S., Wang, Z.L., Ballato, J., Foulger, S.H. and Carroll, D.L. (2003) Monopod, Bipod, Tripod, and Tetrapod Gold Nanocrystals. Journal of the American Chemical Society, 125, 16186-16187. http://dx.doi.org/10.1021/ja038927x

[51] Sau, T.K. and Murphy, C.J. (2004) Room Temperature, High-Yield Synthesis of Multiple Shapes of Gold Nanoparticles in Aqueous Solution. Journal of the American Chemical Society, 126, 8648-8649. http://dx.doi.org/10.1021/ja047846d

[52] Bakshi, M.S. (2009) A Simple Method of Superlattice Formation: Step-by-Step Evaluation of Crystal Growth of Gold Nanoparticles through Seed-Growth Method. Langmuir, 25, 12697-12705. http://dx.doi.org/10.1021/la901767c

[53] Bakshi, M.S. (2010) Room Temperature Surfactant Assisted Crystal Growth of Silver Nanoparticles to Nanoribbons. Journal of Nanoscience and Nanotechnology, 10, 1757-1765. http://dx.doi.org/10.1166/jnn.2010.2051

[54] Al-Lohedan, H.A. (1995) Quantitative Treatment of Micellar Effects upon Nucleophilic Substitution. Journal of the Chemical Society, Perkin Transactions, 2, 1707-1713. http://dx.doi.org/10.1039/p29950001707

[55] Tascioglu, S. (1996) Micellar Solutions as Reaction Media. Tetrahedron, 52, 11113-11152. http://dx.doi.org/10.1016/0040-4020(96)00669-2

[56] Bunton, C.A. (1997) Reactivity in Aqueous Association Colloids. Descriptive Utility of the Pseudophase Model. Journal of Molecular Liquids, 72, 231-249. http://dx.doi.org/10.1016/S0167-7322(97)00040-8 